\title{
ARTICLE
}

\section{Rapid and efficient ATM mutation detection by fluorescent chemical cleavage of mismatch: identification of four novel mutations}

\author{
Louise Izatt ${ }^{1}$, Carina Vessey ${ }^{2}$, Shirley V Hodgson ${ }^{1}$ and Ellen Solomon ${ }^{1}$ \\ ${ }^{1}$ D ivision of M edical and M olecular Genetics GKT, G uy's H ospital, L ondon \\ ${ }^{2}$ ICRF M olecular O ncology L aboratory, U niversity of Oxford Institute of M olecular M edicine, John Radcliffe \\ H ospital, Oxford, UK
}

\begin{abstract}
M utations in the $A$ taxia Telangiectasia M utated (ATM) gene are responsible for the autosomal recessive disease $A$ taxia Telangiectasia (A - T ). A wide variety of mutations scattered across the entire coding region ( $9168 \mathrm{bp}$ ) of ATM have been found, which presents a challenge in developing an efficient mutation screening strategy for detecting unknown mutations. Fluorescent chemical cleavage of mismatch (FCCM) is an ideal mutation screening method, offering a non-radioactive alternative to other techniques such as restriction endonuclease fingerprinting (REF). U sing FCCM, we have developed an efficient, accurate and sensitive mutation detection method for screening RT-PCR products for ATM mutations. We have identified seven ATM mutations in five A -T families, four of which are previously unknown. We quantified ATM protein expression in four of the families and found variable ATM protein expression (0-6.4\%), further evidence for mutant ATM protein expression in both classic and variant A -T patients. We conclude that FCCM offers a robust ATM mutation detection method and can be used to screen for ATM mutations in cancer-prone populations.
\end{abstract}

Keywords: ataxia telangiectasia; ATM ; mutation detection; fluorescent chemical cleavage of mismatch; protein expression

\section{Introduction}

A taxia telangiectasia $(A-T)$ is an autosomal recessive disease affecting $1 / 40000$ to $1 / 300000$ individuals worldwide. ${ }^{1,2}$ This complex disorder is characterised by progressive cerebellar degeneration, oculocutaneous telangiectasia, oculomotor apraxia, immunodeficiency, raised serum $\alpha$-fetoprotein (A FP), chromosomal instability, radiosensitivity, and a 100-fold increase in cancer

Correspondence: $\mathrm{Dr} \mathrm{L}$ Izatt, Division of Medical and Molecular Genetics GKT, 8th floor Guy's Tower, Guy's H ospital, London SE 1 9RT, UK. Tel: +171 955 4648; Fax: + 171955 4644; E -mail: I.izatt@umds.ac.uk

Received 8 September 1998; revised 23 October 1998; accepted 3 November 1998 susceptibility, with lymphoreticular malignancies predominating. ${ }^{3}$ Epidemiological studies have reported increased cancer susceptibility in A-T heterozygotes, particularly to breast cancer in women, ${ }^{4}$ but debate continues over the role of A - T carrier status in breast cancer predisposition. ${ }^{5}$

The A-T gene, A taxia Telangiectasia Mutated (ATM ), was mapped to chromosome 11q22-23 in 1988, ${ }^{6}$ and was isolated by positional cloning in $1995 .{ }^{7}$ ATM is a large, complex gene, with 66 exons, spanning over $150 \mathrm{~kb}$, with the start codon in exon $4{ }^{8,9}$ This generates a $13 \mathrm{~kb}$ transcript, with an open reading frame of $9168 \mathrm{bp}$, predicting a protein of 3056 amino acids. ${ }^{10}$ The ATM protein (about $350 \mathrm{kD}$ a) is located primarily in the nucleus of normal cells ${ }^{11}$ and has homology at its 
carboxy terminus to phosphatidylinositol (PI) 3-kinase. R elated proteins that share PI 3-kinase domain homology are found in yeast (TELI, MEC1, Rad3, TOR 1, and TOR 2), D rosophila (M ei-41) and mammals (DNA PK), (Savitsky et al ${ }^{10}$ for a review). PI 3-kinase family members are involved in a wide variety of regulatory events, including processing DNA damage, maintenance of genome stability and control of cell cycle progression. ${ }^{10}$

Over 250ATM mutations have been reported to date, spanning the entire coding region. ${ }^{12}$ No mutational hotspots have been found, although some founder mutations have been identified. ${ }^{13,14}$ M ost groups have developed scanning methods using CDNA to identify ATM mutations. Techniques include PTT, ${ }^{15}$ SSCP, ${ }^{16}$ RNA se cleavage, ${ }^{17}$ and REF. ${ }^{18}$ Others have used direct sequencing of CDNA. ${ }^{19}$ The overall mutation detection rate has been high (about $70 \%$ ), with base substitutions, small deletions and insertions predominating, resulting in truncation of the ATM protein. ${ }^{12} \mathrm{~A} n$ increasing number of in-frame deletions and missense mutations have recently been described. ${ }^{13}$

We chose solid-phase fluorescent chemical cleavage of mismatch (FCCM) to screen the entire ATM transcript, because it offers efficient and sensitive mutation detection, without bias towards any particular mutation type. Solid-phase FCCM has been used to detect mutations in other large, complex genes, eg Factor IX ${ }^{20}$ and BRCA $1_{1}^{21}$ with almost $100 \%$ accuracy, $^{20}$ locating any sequence change in long DNA segments (up to $1.8 \mathrm{~kb}$ ). We describe its adaptation to detect ATM mutations using CDNA, with the aim of characterising mutations in A-T families for develop- ment of mutation-based prenatal diagnosis. This method is being extended to screen breast cancer patients for germline ATM mutations. In this study, we describe the identification of seven ATM mutations in five A -T families screened using FCCM , (four of which have not been previously identified), and examine expression of the mutant ATM protein.

\section{Materials and Methods}

\section{Patients}

Five non-consanguineous A -T families gave informed consent for this study. Their clinical features are listed in Table 1. Family 347 had two affected daughters; all other families had one affected child. The affected individuals, A -T 347, A -T 352, A - T 451, and A-T 537 have a classic A -T phenotype, whilst $A-T 350$ exhibits a variant A-T phenotype. ${ }^{22}$

\section{Controls}

DNA was isolated from 50 Caucasian males without a family history of A - T or cancer. BD 2685 is a lymphoblastoid cell line $(\mathrm{LCL})$ established from a breast cancer patient, negative for ATM mutations screened by FCCM. M olt 4 is a T cell LCL.

\section{Molecular Methods}

DNA and RNA were isolated from peripheral blood samples by standard methods. ${ }^{23,24}$ Reverse transcription was performed on $0.5-1 \mu \mathrm{g}$ of total RNA with $0.5 \mu \mathrm{g}$ random hexamers primer. ${ }^{25}$

The ATM coding sequence was amplified from patientderived CDNA s by nested PCR, in eight first round reactions, serving as templates for nine overlapping second round reactions, 0.9 to $1.7 \mathrm{~kb}$ in size (Figure 1 ).

Careful primer design allowed all primary and nested $R T-P C R$ reactions to be amplified using one of two sets of conditions (primer details, Table 2). The PCR reaction mixture contained $200 \mu \mathrm{m}$ dNTPs, $500 \mathrm{~nm}$ of each primer set (Table 2), $1.5 \mathrm{~mm} \mathrm{M} \mathrm{gCl} 2$ Taq buffer (Promega, Southampton,

Table 1 Clinical and laboratory features of A -T patients in the study

\begin{tabular}{|c|c|c|c|c|c|c|}
\hline \multirow{2}{*}{$\frac{\text { Clinical feature }}{\text { Family number }}$} & \multicolumn{6}{|c|}{ Patient data } \\
\hline & 537 & 350 & 352 & 451 & $347^{a}$ & $347^{a}$ \\
\hline A ge (years) & 5 & 37 & 16 & 21 & 6 & 4 \\
\hline Sex & $M$ & $\mathrm{~F}$ & $M$ & $\mathrm{~F}$ & $\mathrm{~F}$ & $\mathrm{~F}$ \\
\hline A ge of onset of ataxia (years) & 1 & 1 & 1 & 2 & 1 & 1 \\
\hline Telangiectasia & + & + & + & + & + & + \\
\hline$R$ aised A FP & + & + & + & + & + & + \\
\hline Immunodeficiency & + & - & $\mathrm{NT}^{\mathrm{b}}$ & + & $-{ }^{c}$ & $t^{c}$ \\
\hline M alignancy & - & - & - & - & - & - \\
\hline R adiosensitivity & Classical & Intermediate $^{d}$ & Classical & Classical & Classical & Classical \\
\hline Chromosomal rearrangements & + & + & + & + & + & + \\
\hline Clinical progression & Classical $^{\mathrm{e}}$ & D elayed $^{\dagger}$ & Classical $^{\mathrm{e}}$ & Classical $^{e}$ & Classical $^{e}$ & Classical $^{\mathrm{e}}$ \\
\hline
\end{tabular}

${ }^{a}$ These are two siblings from the same family; ${ }^{\mathrm{N}} \mathrm{NT}=$ not tested; I Intrafamilial phenotypic variation in their measured immune function (I gM, I gA, and IgG subclasses) and frequency of infections; ${ }^{d} \mathrm{R}$ adiosensitivity measured in lymphocyte chromosomes exposed to $1 \mathrm{G}$ y X-rays at $\mathrm{G}_{2}$ was intermediate between control patients and the high level observed in classical A - T patients, see Taylor et al,${ }^{45}$ C Classical clinical progression - for fuller description, see B undey ${ }_{i}^{46} \mathrm{f}$ elayed clinical progression observed, eg moderate gait ataxia at age 37 , see $\mathrm{M}$ cC onville et al. 
U.K.), $1 \cup$ Taq polymerase (Promega), and $1 \cup$ Taq extender (Stratagene, Cambridge, U.K.). $1 \mu$ l cDNA served as the template for the first round PCR; and $1 \mu$ l of first round PCR product, as the template in the second round PCR. Second round PCR products were internally labelled by incorporation of $1.5 \mu \mathrm{M} R 6 \mathrm{G}$ or R 110, or $6 \mu \mathrm{M}$ TAMRA fluorescent dUTPs ([F]dU TPs) (Perkin Elmer, Warrington, U.K.) (Figure 1). PCR conditions for first round PCR for all fragments, except $1 \mathrm{~A} \mathrm{~F} / 2 \mathrm{BR}$ (Figure 1 ), comprised 30 cycles of $94^{\circ} \mathrm{C}, 30 \mathrm{~s}$, $55^{\circ} \mathrm{C}, 30 \mathrm{~s}$, and $72^{\circ} \mathrm{C}, 2 \mathrm{~min}$, followed by a $10 \mathrm{~min}$ extension at $72^{\circ} \mathrm{C}$. Touchdown $P C R^{26}$ was used to amplify second round $P C R$ reactions, fragment $1 A F / 2 B R$ (Figure 1 ), the promoter fragment, and all probes. Conditions used were as follows: 30 cycles of $94^{\circ} \mathrm{C}, 30 \mathrm{~s}, 64^{\circ} \mathrm{C}, 30 \mathrm{~s}$ (for 5 cycles, then $60^{\circ} \mathrm{C}$ for 25 cycles), and $68^{\circ} \mathrm{C}, 90 \mathrm{~s}$, and final extension at $68^{\circ} \mathrm{C}$ for $5 \mathrm{~min}$. The promoter region was amplified from $100 \mathrm{ng}$ of genomic DNA. Probe DNA was amplified using a modified second round primer set, (each primer biotinylated at the $5^{\prime}$ end), internally labelled with [F]dUTPs, and gel-purified. CD NA clones (FB2-f, FB-2 and 7-9) ${ }^{10}$ and a partial subclone of E n-a (extending from -30 to 2028; Nucleotide numbering according to Savitsky et $\mathrm{al}^{10}$ ), ${ }^{48}$ served as probe templates (Figure 1), except for fragment III, where a PCR product of known sequence was used.

\section{Mutation Detection}

Solid-phase fluorescent chemical cleavage of mismatch (FCCM ) was used to identify ATM mutations ${ }^{20}$ with modifications detailed below.

Three separate, non-overlapping multiplexes were formed by labelling nested PCR fragments as described (see legend, Figure 1). $1 \mu$ of each biotinylated internally labelled probe, was combined with $4 \mu$ linternally labelled target per multiplex, favouring maximum heteroduplex formation between probe and patient DNA. H eteroduplex formation and chemical mismatch were as described, ${ }^{20}$ using hydroxylamine and osmium tetroxide modification sequentially.

$2 \mu \mathrm{l}$ of supernatant was loaded on a $6 \%$ polyacrylamide/ urea gel (34lane, $12 \mathrm{~cm}$ well-to-read plates) on the A BI 377 D NA sequencer and separated by electrophoresis at $50 \mathrm{~W}$ for
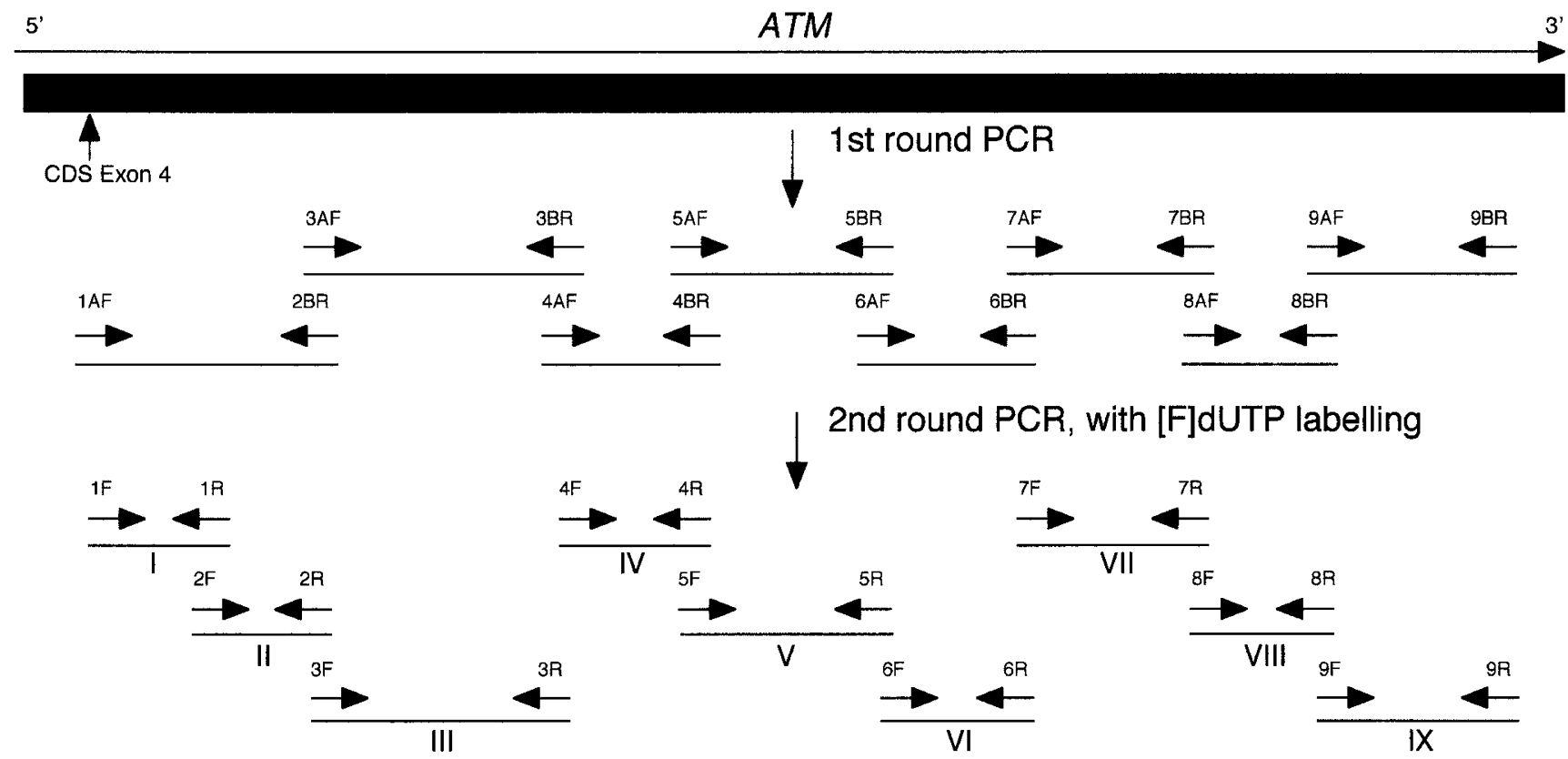

Cloned DNA, used for probes

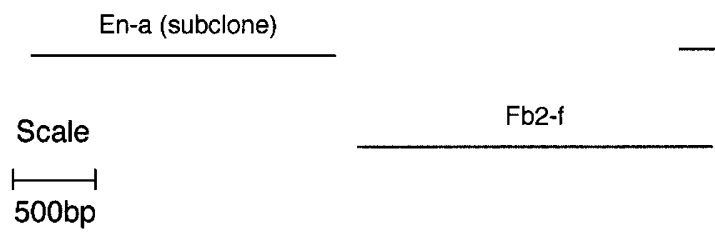

$\mathrm{Fb} 2$

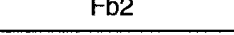

$7-9$

Figure 1 Generation of PCR products for FCCM mutation analysis of ATM. Schematic representation of the ATM transcript showing RT-PCR amplified fragments and the position of CD NA clones, ${ }^{10}$ amplified as probes for all fragments, except fragment III. The primer sequences and their positions are listed in Table2. Fragments I and II are amplified as one primary fragment, but divided into two smaller second round products because of alternate splicing observed (results not shown). Nested second round PCR products are internally labelled by one of three fluorescent dyes ([F]dUTPS): R 110, R 6G, and TAM RA. PCR products V, VIII, and IX are labelled by R 110; I, III, and IV by R 6G; and II, VI, and VII by TA M RA. Three non-overlapping, differently labelled PCR products are combined and analysed concurrently. M ultiplex A : products II, IV, VIII; M ultiplex B: products III , VI, IX; M ultiplex C: products I, V, VII. 
Table 2 Primers used in FCCM analysis and genomic sequencing

\begin{tabular}{|c|c|c|c|c|c|}
\hline Primer & Forward primer sequence $5^{\prime} \rightarrow 3^{\prime}$ & Primer & Reverse primer sequence $5^{\prime} \rightarrow 3^{\prime}$ & \multicolumn{2}{|l|}{ ATM position } \\
\hline \multicolumn{6}{|c|}{ First round primers } \\
\hline IAF & GTGAGGCATACATCACAATTTGG & 2BR & GGTCTGCAGGCTGACCCAG & $-120-1601^{a}$ & \\
\hline BA F & GCCTTACG GAAGTTGCATTG & 3BR & CCCATTACATTA A GAATGGC & $1373-3194^{\mathrm{a}}$ & \\
\hline $4 \mathrm{AF}$ & GATGTTCTTGAACTTCTG & 4BR & TTGCTGGCTCATGTAACGTC & $2893-4066^{a}$ & \\
\hline $5 A F$ & TCTATAGATCTTGTTATA AGG & 5BR & AGGTA ACA GCTGCTGATCGAA & $3740-5206^{a}$ & \\
\hline 6AF & GGCAATA A A CCACACTGGTG & 6BR & CCCACATTGCTTCGTGTTC & $4971-6127^{\mathrm{a}}$ & \\
\hline $7 A F$ & AGCCAGAGTACA ACTATTTC & 7BR & AGCCAGAGTGCAACTATTTC & $5941-7277^{\text {a }}$ & \\
\hline $8 \mathrm{AF}$ & AGAAAAGGCAGTAGAAGTTGC & 8BR & CCTGCTAAGCGAAATTCTGC & $7083-8081^{a}$ & \\
\hline $9 A F$ & ACTCAGTGGAAGACTCAGAG & 9BR & CTACTTA A A GTATGTTGGCAG & $7906-3^{\prime} U T R{ }^{a}$ & \\
\hline \multicolumn{5}{|c|}{ Second round primers } & Overlap ${ }^{c}$ \\
\hline $1 F$ & CAGTGATGTGTGTTCTGAAATTG & $1 R$ & GCACCTTTTTCTTGGGTTTTGGC & $-28-905^{a}$ & \\
\hline $2 \mathrm{~F}$ & GCTATTCAGTGTGCGAGACAAG & $2 \mathrm{R}$ & TGGCTCCAAGTAAGCCAAAG & $646-1531^{a}$ & 259 \\
\hline $3 \mathrm{~F}$ & GAGGTCAAACCTAGAAAGCTCAC & $3 R$ & ССTCTCCTTGTTAGATGCC & $1404-3096^{a}$ & 127 \\
\hline $4 \mathrm{~F}$ & CTAGGTCA A A GCA ATATGGACTC & $4 \mathrm{R}$ & СA ATCTGTTTTCCCA ATA A GTTTTC & $3001-3997^{\mathrm{a}}$ & 95 \\
\hline $5 F$ & CCACATCTGGTGATTAGAAGTCA & $5 R$ & GCATTATTATGATGGTCCACTGAAG & $3769-5143^{a}$ & 228 \\
\hline $6 F$ & CCTATAGATTTCTCTA CCATAGC & $6 R$ & GTTCGTAGTCTAGTAATGGGTTG & $5038-6104$ & 105 \\
\hline $7 \mathrm{~F}$ & CTGGA ATA A GTTTA CA G GATCTTC & $7 R$ & GATGATTCATGTAGTTTTCAATTC & $5990-7223^{a}$ & 114 \\
\hline $8 \mathrm{~F}$ & GATGGAGAAAGTAGTGATGAGC & $8 R$ & AGTCACCAGATTTCCATATTCTC & $7114-8046^{a}$ & 109 \\
\hline $9 F$ & CCAGCAGACCAGCCAATTACTA & $9 R$ & AAGGCTGAATGAAAGGGTA ATTC & $7942-9206^{a}$ & 104 \\
\hline \multicolumn{6}{|c|}{ Promoter primers } \\
\hline PromF & CAAGCCGGGCTACGTCCGAGGGTAACAACAT & PromR & CTGCACTCGGAAGGTCAAAGTAGTATCAAC & $10207-10882^{b}$ & \\
\hline \multicolumn{6}{|c|}{ Sequencing primers } \\
\hline $96508 \mathrm{~F}$ & CTTCTGGTTATTTTACCTTAGAG & $5856 \mathrm{R}$ & GTTTTTGCCCAACATACTGTAC & & \\
\hline Exon 7F & GTTGCCATTCCAAGTGTCTTA & xon 7R & CA A ACA ACA ACCTTCA A A ACA & & \\
\hline Exon IIAF & CAGGTTTTTAATGAAGATACCAG & xon $11 R$ & GAATGAGAAAATGGTAACACTT & & \\
\hline Exon 12FF & CA ACCCA ATTA ATATCAAAG & xon $12 A R$ & A ATAAATCTGACTTTTGTGAG & & \\
\hline Exon $23 \mathrm{AF}$ & CTTTTAGCTTGAATTTTTGG & xon $23 R$ & TGGTTAAATATGAAATAGAG & & \\
\hline Exon $31 F$ & CCGAGTATCTA ATTA A A CA AG & xon $31 R$ & CAGGATAGA A A GACTGCTTAT & & \\
\hline Exon 65F & TTA A ACTGTTCACCTCACTGA & $3 R$ & CTACTTAAAGTATGTTGGCAG & & \\
\hline
\end{tabular}

${ }^{a}$ The first nucleotide of the open reading frame was designated at $+1, \mathrm{GDB}^{47}: \mathrm{U} 33841$ Savitsky et al; ${ }^{10} \mathrm{~b}$ nucleotide numbers refer to the genomic sequence with the first nucleotide designated $+1, \mathrm{GDB}:{ }^{47}$ U 82828 Platzer et al; ' $\mathrm{c}^{\mathrm{c}}$ the overlap, in base pairs, corresponds to the overlap between that fragment and the $5^{\prime}$ neighbouring fragment. 
5-7h using GS12A -2400. D ata was collected and analysed using Genescan 2.02 software (ABI Prism, Warrington, U.K.).

\section{DNA Sequencing and Restriction Assays}

RT-PCR was repeated without labelling, and products sequenced in both directions. ${ }^{27}$ Sequence variants were confirmed by PCR and sequencing genomic DNA, using primers listed (Table 2).

For the L 1465P mutation, a naturally occurring restriction site was created in exon 31 by the base substitution, allowing $\mathrm{X}$ hol digestion in mutant alleles.

\section{Cell Lines/Western Blotting}

Control BD 2685, and four A -T patient LCL s were cultured in R PM I 1640 (Gibco BRL, Paisley, U.K.) with $10 \%$ foetal calf serum. Total cellular lysate preparation was as described. ${ }^{14}$ $50 \mu \mathrm{g}$ protein was loaded per lane, separated electrophoretically through 7.5\% SD S-Polyacrylamide gels, and blotted on to nitrocellulose membranes (I mmobilonP-Millipore, Bedford, MA, USA) by semi-dry transfer. ATM protein was detected with a polyclonal antiserum $(\mathrm{CN}-12)$ raised against a recombinant polypeptide corresponding to 992-1144 of A TM protein. A $\beta$-tubulin monoclonal antibody (A mersham, Little Chalfont, Bucks, U.K.) was used to quantitate protein loading. Western blotting was as described ${ }^{28}$ and blots were developed by enhanced chemiluminescence (A mersham). Protein levels were measured using the Biolmage Whole
B and A nalyser system (Millipore), normalised against $\beta$-tubulin readings, using BD 2685 as a standard.

\section{Results}

\section{FCCM on Patient Samples}

The optimised multiplexed FCCM technique was used to screen A -T patient samples, allowing analysis of the entire ATM coding region of up to ten patients per gel. Cleavage bands detected by $\mathrm{G}$ enescan analysis were used to predict the mismatched base site within the fragment (Figures $2 \mathrm{~A}$ and $2 \mathrm{~B}$ ). A ccurate sizing of the two separate cleavage products on the electropherogram enables location of the mismatched base to within 10-15 bp of one of two sites in the fragment screened (Figures $2 \mathrm{C}$ and 2D).

Seven different ATM mutations were detected in five A - T families analysed (Table 3 ). Four of these, 480del5, 1158delG, IV S22-1G $\rightarrow$ A, and 4394T $\rightarrow$ C, are novel.

\section{Frameshift Mutations}

The 480del5 mutation in ATM exon 7 detected in A -T 347 was seen in both affected siblings in this family and
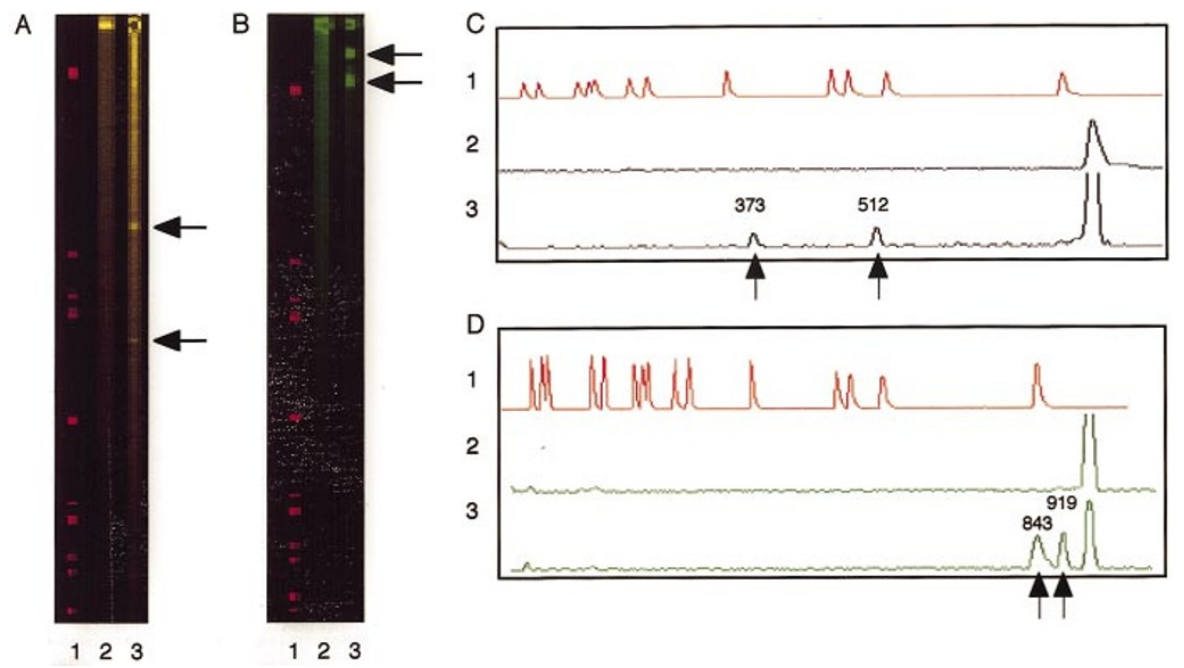

Figure 2 D etection of ATM gene mutations by FCCM. G el images and electropherograms of mismatch cleavage products detected in A-T 537. A and C: FCCM of ATM fragment II, internally labelled with TA M RA. H eteroduplexes were formed between probe D NA (clone En-a) and RT-PCR products from A -T 537, subjected to hydroxylamine treatment and separated by electrophoresis on a $6 \%$ polyacrylamide gel. Lane 1: Genescan Rox-2500 marker (Perkin Elmer). Lane 2: Probe DNA only. Lane 3: 537/probe DNA heteroduplex. A mismatched base is detected, generating two shorter products ( $373 / 512 \mathrm{bp}$ ). These add up to the full-length of fragment II , $885 \mathrm{bp}$ ( $\mathrm{L}$ ane 3), shown best in the electropherogram image in $\mathbf{C}$. The mutation lies at one of these two sites, but cannot be assigned to sense or antisense strands because both strands are internally labelled. Sequencing, shown in Figure $3 \mathrm{~A}$, revealed a 1 bp deletion, 1158delG in exon 11. B and D : FCCM of ATM fragment IV, internally labelled with R6G. H eteroduplexes were formed between probe DNA (clone FB 2-f) and RT-PCR products from A-T 537, subjected to hydroxylamine treatment and separated by electrophoresis on a 6\% polyacrylamide gel. $L$ ane 1: G enescan Rox-2500 marker (Perkin E Imer). L ane 2: Probe D NA only. L ane 3: 537/probe D NA heteroduplex. Two shorter fragments, below the full-length band of $996 \mathrm{bp}$ can be seen in $L$ ane 3 , corresponding to the boundaries of exon 23 , which is $76 \mathrm{bp}$ in length. The mismatch is sized more accurately (919/843 bp) from the electropherogram image shown in $\mathbf{D}$. Sequencing of genomic DNA, shown in Figure $3 C$, revealed the mutation IVS22-1G $\rightarrow$ A. A rrows indicate mismatch bands due to mutations and numbers correspond to the size of each mismatch band detected. 
Table 3 ATM mutations in A-T families identified by FCCM

\begin{tabular}{|c|c|c|c|c|c|c|}
\hline A-T patient & Ethnic origin ${ }^{a}$ & Genomic mutation $^{\mathrm{b}}$ & Transcript mutation $^{c}$ & Predicted protein alteration & Exon/intron $^{c}$ & Heterozygosity $^{d}$ \\
\hline 347 & Irish $^{\mathrm{p}}$ & 5-bp deletion in exon 7 & 480del5 & $\begin{array}{l}\text { Frameshift at codon } 160 \text {, leading to a stop } \\
\text { codon after } 23 \text { amino acids }\end{array}$ & 7 & Cpd het ${ }^{e}$ \\
\hline 347 & Greek-Cypriot $^{\mathrm{m}}$ & $?$ & & & & Cpd het \\
\hline 350 & English $^{\mathrm{p}}$ & IVS40-1050A $\rightarrow$ G & $5762^{\wedge} 5763$ ins $137^{f}$ & $\begin{array}{l}\text { Frameshift at codon } 1921 \text {, leading to a stop } \\
\text { codon after } 9 \text { amino acids }\end{array}$ & IVS40 & Cpd het \\
\hline 350 & English $^{\mathrm{m}}$ & $\begin{array}{l}\text { Base substitition in } \\
\text { exon } 65\end{array}$ & $9139 \mathrm{C} \rightarrow \mathrm{T}$ & A rg $\rightarrow$ ter at codon 3047 & 65 & Cpd het \\
\hline 352 & English & ? & & & & NK \\
\hline 352 & English & ? & & & & NK \\
\hline 451 & English $^{\mathrm{m}}$ & 1-bp deletion in exon 12 & 1355delC & $\begin{array}{l}\text { Frameshift at codon } 452 \text {, leading to a stop } \\
\text { codon after } 20 \text { amino acids }\end{array}$ & 12 & Cpd het \\
\hline 451 & English $^{p}$ & $\begin{array}{l}\text { Base substitution in } \\
\text { exon } 31\end{array}$ & $4394 \mathrm{~T} \rightarrow \mathrm{C}$ & Leucine to proline at codon 1465 & 31 & Cpd het \\
\hline 537 & Irish $^{\mathrm{m}}$ & 1-bp deletion in exon 11 & 1158delG & $\begin{array}{l}\text { Frameshift at codon } 386 \text {, leading to a stop } \\
\text { codon after } 3 \text { amino acids }\end{array}$ & 11 & Cpd het \\
\hline 537 & Irish $^{\mathrm{p}}$ & IVS22-1G $\rightarrow \mathrm{A}$ & $\begin{array}{l}3078-1 \mathrm{G} \rightarrow \mathrm{A} \\
\text { (exon } 23 \text { deleted) }\end{array}$ & $\begin{array}{l}\text { Deletion of } 26 \text { amino acids at codon 1026, } \\
\text { leading to a stop codon after } 2 \text { amino acids } \\
\text { in exon } 24\end{array}$ & IVS22 & Cpd het \\
\hline
\end{tabular}

${ }^{a}=$ allele, ${ }^{p}=$ paternal allele, ${ }^{m}=$ maternal allele; ${ }^{b}=$ exon numbers are according to $\mathrm{U}$ ziel et al $;{ }^{8 c}=$ mutations are as proposed by the Nomenclature Working $\mathrm{G}$ roup. ${ }^{48}$ The first nucleotide of the open reading frame was designated as $+1, \mathrm{GDB}{ }^{4}$ : U 33841; ${ }^{\circ} \mathrm{Cpd}$ het: compound heterozygote; NK: not known; $=$ second allele expressed at the RT-PCR level, detected on sequencing RT-PCR product; $=137 \mathrm{bp}$ of intron 40 aberrantly spliced into the A -T transcript between exon 40 and 41 ; mutations were confirmed by amplification and sequence analysis of genomic PCR products using primers listed in Table 2. 
their father (results not shown) (Table 3). Sequencing of the RT-PCR product in A-T 347 showed bi-allelic expression (results not shown). This $5 \mathrm{bp}$ deletion (underlined) is associated with a direct repeat (italicised) in the DNA sequence TA TCTCA G CA A CA. The 1158delG mutation in ATM exon 11 was detected in A -T 537 and his mother (results not shown) (Table 3; Figure $3 \mathrm{~A}$ ). This deletion (underlined) occurs in a run of homonucleotides (italicised) CAAAAGGAAGA. These two deletions may occur as a result of DNA slippage during replication. The $1355 \mathrm{delC}$ in ATM exon 12, found in A-T 451, (Table3) was described previously. ${ }^{13}$

\section{Splicing Mutations}

Two close mismatch bands were detected in fragment IV from A-T 537 (Figures 2B and 2D). Sequencing CDNA across this region identified exon 23 skipping in A-T 537 (Figure 3B), deleting $76 \mathrm{bp}$, resulting in a frameshift in exon 24 (Table 3). Sequence analysis of genomic DNA from A - T 537 revealed IV S22-1G $\rightarrow$ A at the intron 22-exon 23 splicing junction (Figure 3C; Table 3). This mutation alters the invariant splicing acceptor site from $A G$ to $A A$, explaining the observed exon 23 skipping (Figure $3 B$ ). This splicing variant is unlikely to occur in the absence of the splice site mutation, because it was not observed in FCCM analysis of 250 chromosomes from A-T and breast cancer families, but was found in the father of A -T 537 (results not shown). IV S40-1050A $\rightarrow G$, found in A-T 350, was described previously, ${ }^{29}$ (Table 3).

\section{Nonsense/Missense Mutations}

The 4394T $\rightarrow C$ base substitution found in ATM exon 31 in A-T 451 results in a leucine-to-proline amino acid substitution at codon 1465 (Table 3). This base change creates an X hol cutting site in the exon 31 PCR product of $294 \mathrm{bp}$. U pon digestion, the mutant allele gives rise to two fragments of $206 \mathrm{bp}$ and $88 \mathrm{bp}$, while the normal allele is resistant to $\mathrm{X}$ hol digestion, giving an undigested fragment of $294 \mathrm{bp}$ (Figure 4). 4394T $\rightarrow C$, is unlikely to be a polymorphism, since this base change was not detected after PCR and Xhol digestion of 100 control chromosomes (results not shown), and because leucine is conserved at this position in mouse A tm. ${ }^{30}$

The $9139 \mathrm{C} \rightarrow T$ single base substitution in ATM exon 65 found in A -T 350 creates a stop codon at 3047, with loss of ten amino acids from the $\mathrm{C}$-terminus of the protein. This mutation has been described previously. ${ }^{29}$
Two other coding sequence variations were detected in A - T 537 and A-T 451, both patients being heterozygous for polymorphism 5557G/A (exon 39). No sequence variations were detected in A - T 352.

\section{Western Blotting}

A TM protein expression was investigated in four of the A -T families where LCLs were available, to examine the consequences of different ATM mutations on protein expression and clinical phenotype (Figure 5). The highest amount of full-length ATM protein observed $(6.4 \%)$ was in A-T 350 (Figure 5). The presence of full-length ATM protein occurs as a result of some normal splicing at IV S40-1050A $\rightarrow \mathrm{G}^{29}$ and expression of some stable minimally truncated ATM protein from $9139 \mathrm{C} \rightarrow \mathrm{T} .{ }^{31}$ This patient exhibits a variant phenotype (Table 1). A -T 451 and A -T 347 have classic phenotypes (Table 1 ) and significantly reduced fulllength ATM expression (Figure 5). Each has one truncated A -T allele upstream of the antibody-binding site (Table 3), so that any ATM protein detected must arise from the second allele. In A - T 451, the low level of ATM expression shown (1\%) (Figure5) indicates that the L 1465P missense mutation (Table 3) may lead to instability of the protein. The trace of full-length A TM protein expression in A -T 347 (Figure 5), may indicate that the unidentified mutation is an in-frame deletion/ insertion, or a missense mutation. A TM protein was not detected in A - T 352 (Figure 5).

\section{Mutant Allele Origins}

Three of the five families studied were native to the $B$ ritish I sles. Family 537 , and the father of A - T 347 were of Celtic/l rish origin, whilst the mother of A - T 347 was of $\mathrm{G}$ reek-Cypriot origin (Table 3). O nly one mutation, IV S40-1050A $\rightarrow G$, has previously been shown to be a founder mutation in the British Isles. ${ }^{29}$ A lthough $9139 \mathrm{C} \rightarrow T$ has been described in an Italian, ${ }^{31}$ Japanese, ${ }^{17}$ and UK families, no common haplotype was reported. ${ }^{13}$ We identified all three alleles of Celtic//rish origin, each mutation being novel to this study (Table 3).

\section{Discussion}

We have shown that FCCM is an effective mutation detection method in scanning the entire ATM coding region for mutations. $O$ ur study identified seven out of a possible ten ATM mutations in five A-T families, giving a sensitivity of $70 \%$, comparable with other ATM mutation detection methods used, eg PTT ${ }^{15}$ and RE F. ${ }^{13}$ 
FCCM offers several advantages in comparison with other methods used, screening up to ten A -T patients per gel by multiplexing samples, and accurately locating the variant base within the segment analysed. By labelling both the patient and control DNA samples, an almost twofold redundancy in the ability to detect base

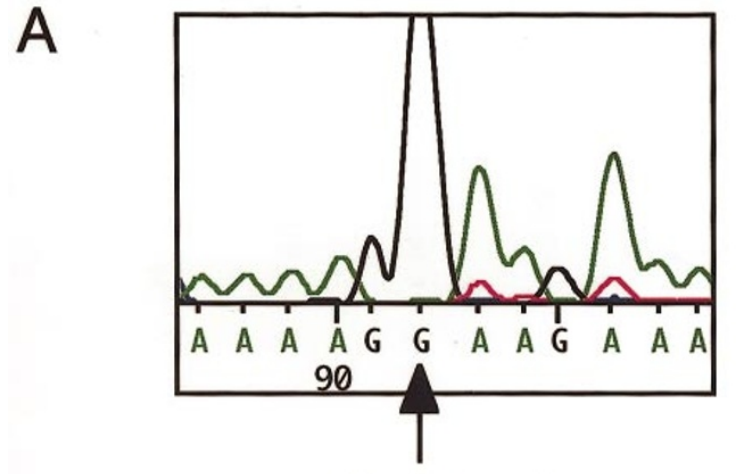

Control: 1158
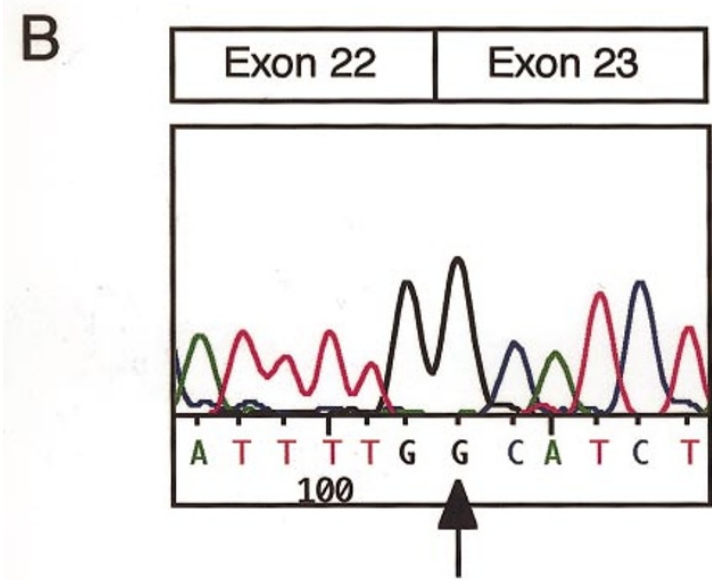

Control: Exon 23 starts

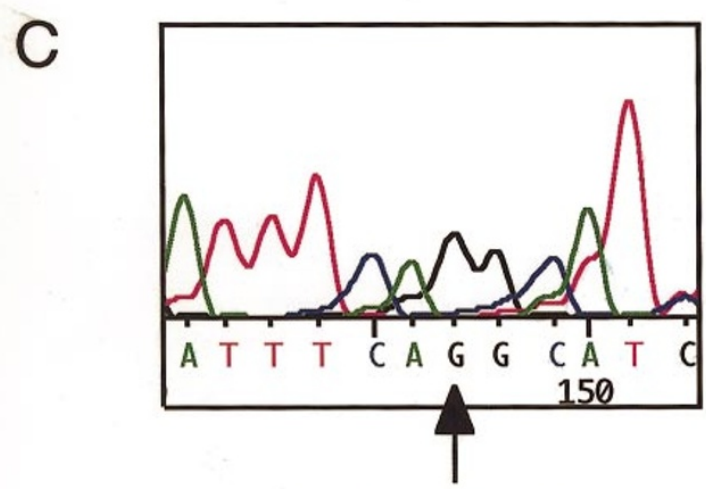

Control: IVS22-1G

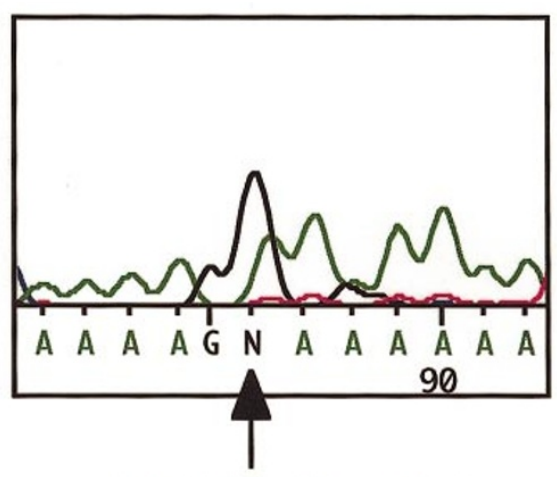

A-T 537: 1158delG

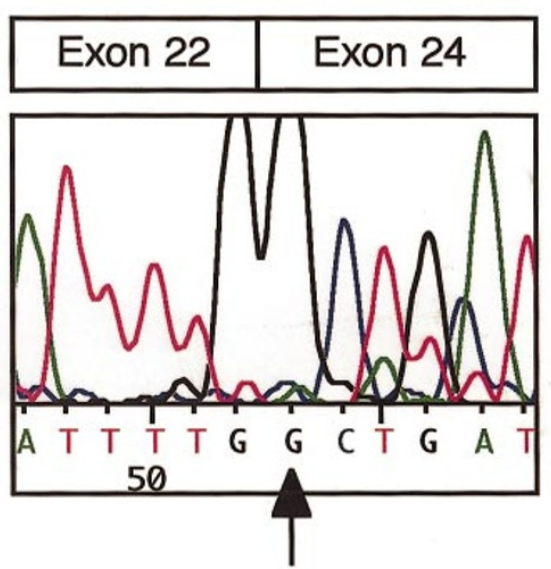

A-T 537: Exon 23 skipped

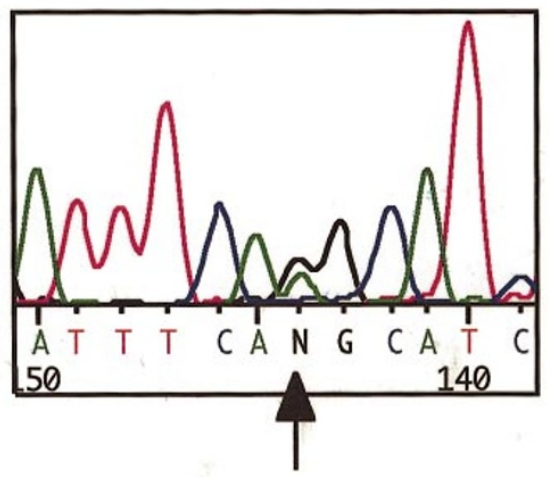

A-T 537: IVS22-1G->A

Figure 3 Sequence analysis of the mismatch bands observed in Figure2. A : I dentification of 1158delG in ATM exon 11 (1) control (Molt 4) and (2) A-T 537. B : Sequence of ATM CDNA across the exon 22/23 boundary in (1) control (FB2-f) and (2) A-T 537 RT-PCR products from fragment IV, showing exon 23 skipping. C: I dentification of genomic mutation underlying skipping of exon 23 observed in A-T 537. Sequencing the acceptor splice site, ATM intron 22/exon 23 revealed IVS22-1G $\rightarrow A$ in A - T 537. (1) control (M olt 4) and (2) A-T 537. A $n$ arrow indicates the mutant base in each instance. 
changes is seen, increasing sensitivity and detection. ${ }^{20}$ If differential mRNA expression of each mutant allele occurs, the sensitivity of FCCM may enable detection

\section{$\begin{array}{lllll}1 & 2 & 3 & 4 & 5\end{array}$}

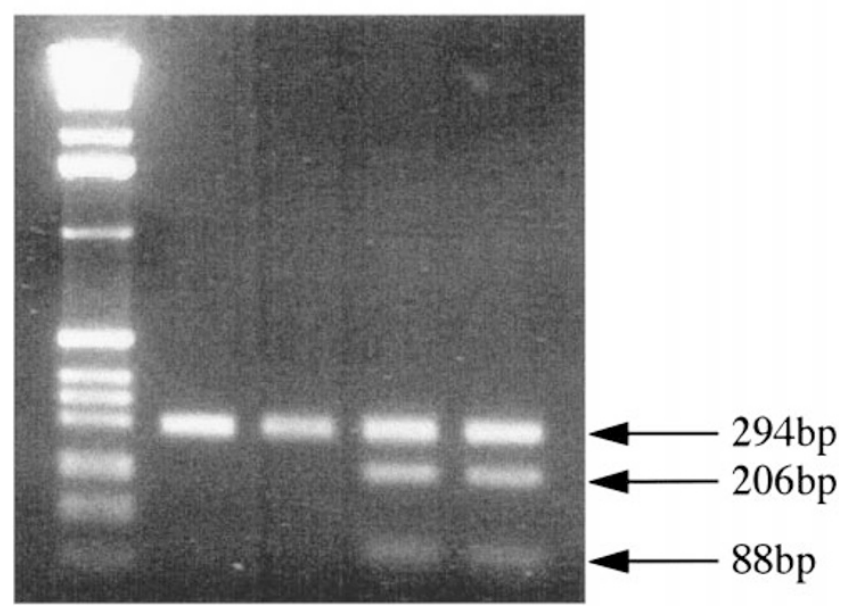

Figure $4 X$ hol digest of ATM exon 31 products in A-T 451. $2 \%$ agarose gel showing detection of the 4394T $\rightarrow C$ ( $L$ 1465P) missense mutation in exon 31 of the ATM gene by PCR (primers listed in Table2) and $X$ hol digestion. 4394T $\rightarrow C$ creates a $X$ hol cutting site, giving digested smaller fragments of $206 \mathrm{bp}$ and $88 \mathrm{bp}$ from the full length PCR product of $294 \mathrm{bp}$. $L$ ane 1: $1 \mathrm{~kb}$ ladder ( $G$ ibco $B R L$ ). $L$ ane 2: Undigested $P C R$ product. $L$ anes $3-5 \mathrm{X}$ hol digested $P C R$ products. $L$ ane 3 : M other of A-T 451; $L$ ane 4: Father of A-T 451; $L$ ane 5: A-T 451. A rrows indicate the full length and digested products of as little as $10 \%$ of the mutant transcript. ${ }^{32}$ Finally, because analysis of FCCM gels is automated, comparisons between samples are easier.

The seven ATM mutations detected in this study reflect the spectrum of ATM mutations already characterised worldwide, with small deletions and exonskipping mutations predominating. Although ATM mutations are found to span the entire open reading frame, our small study showed three deletions occurring in exons 7-12. Exon-skipping mutations have been reported to involve at least 34 of the 66 exons in ATM, but only in about $20 \%$ of instances has the underlying genomic mutation been reported. ${ }^{33}$ We found exon 23 skipping in A - T 537, as a consequence of IV S22-I G $\rightarrow$ A . Exon skipping is the commonest outcome following a mutation in the acceptor splice site; however, cryptic splice site activation, intron retention, and new splice site creation can occur. ${ }^{34}$ There has been one previous description of exon 23 skipping, in tandem with exon 24, but the underlying genomic mutation was not reported. ${ }^{16}$

We detected one new missense mutation ( $L$ 1465P) in ATM, adding to the 24 already reported in A-T patients. ${ }^{33}$ This mutation leads to a proline substitution in the middle of a predicted $\alpha$-helix from amino acids 1460 to 1476 (consensus predictions generated by J pred, ${ }^{35}$ a protein prediction algorithm service). This is predicted to change the secondary structure of the
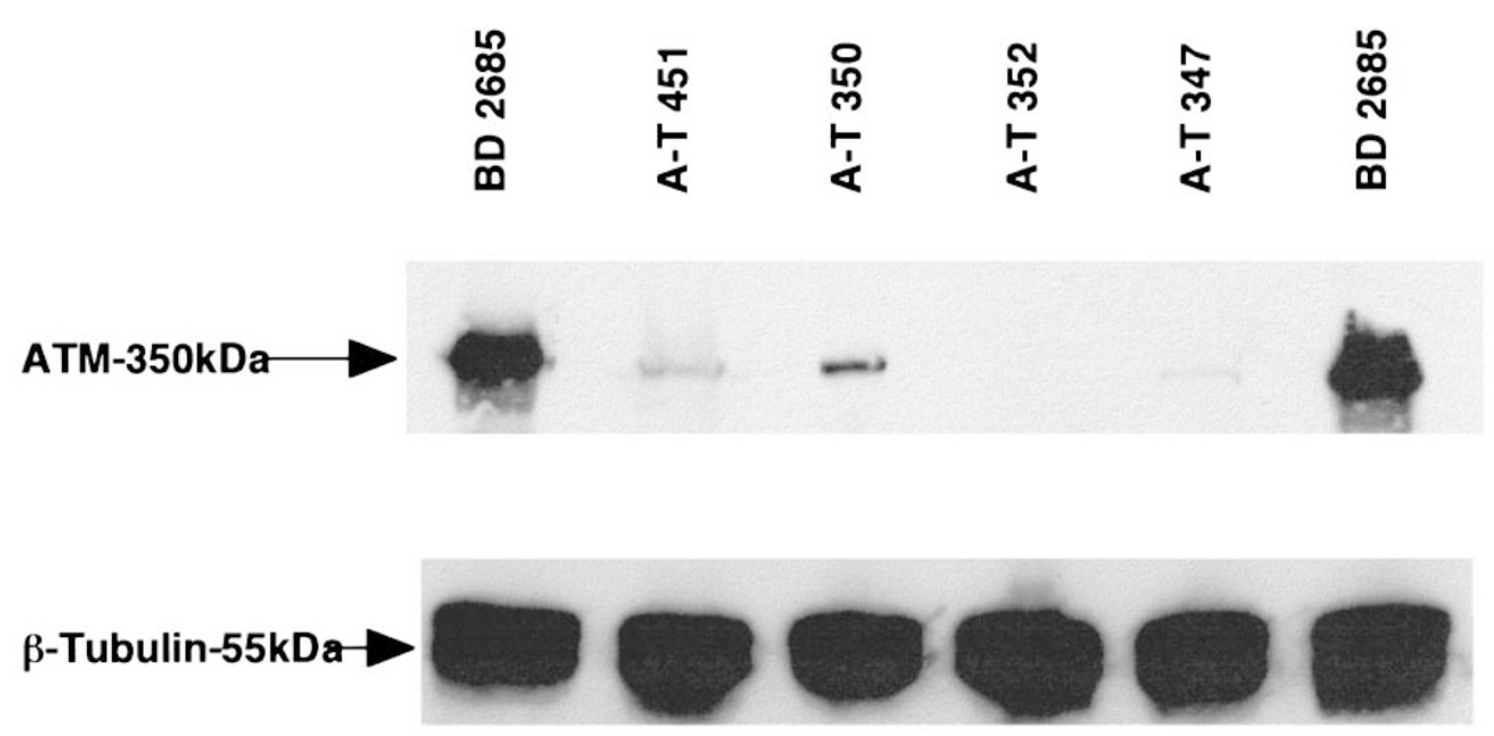

Figure 5 Western analysis of ATM protein extracted from lymphoblastoid cell lines. Whole cell lysates, containing $50 \mu \mathrm{g}$ protein, were fractionated on a $7.5 \%$ SD S-PAGE gel and blotted with polyclonal ATM antibody CN-12, and monoclonal $\beta$-tubulin antibody (A mersham). L ane 1: BD 2685 (Control); $L$ ane 2: A-T 451; L ane 3: A-T 350; $L$ ane 4: A-T 352; L ane 5: A-T 347; L ane 6: BD 2685 (Control) 
protein, destabilising the protein. ${ }^{36}$ Examples of leucine-to-proline substitutions resulting in protein instability are reasonably common, eg $L 12 \mathrm{P}$ in $\lambda$ repressor. ${ }^{37}$ We observed reduced ATM protein expression from this allele in A -T 451, in keeping with this prediction.

By demonstrating reduced or absent ATM protein expression in four cases, we were able to confirm the diagnosis of A-T. Residual ATM protein expression is often associated with alleles harbouring 'leaky' splicing mutations, ${ }^{31}$ as seen in A -T 350, or in-frame deletions, or missense mutations, as seen in A -T 451. Correlation of expressed ATM protein levels with clinical and cellular phenotypic features is difficult, because 'variant' A -T patients have been shown to express 1-100\% of the normal level of ATM protein, ${ }^{13,31}$ and this overlaps with the protein levels seen in classic A-T patients. ${ }^{13}$

Several founder mutations have been described in ATM , including eleven recurrent ATM mutations in the B ritish I sles. ${ }^{13}$ Two of these, 2639del200nt (codon 880), and 7639del9nt (codon 2546-2548), were found in families of I rish/Celtic descent. ${ }^{38}$ Three of our A -T alleles were of Celtic//rish origin, but did not share these founder mutations.

Three ATM alleles were not detected in this study, despite analysing the ATM /E 14 bi-directional promoter region for mutations. ATM promoter mutations have not been found in A - T patients, ${ }^{39}$ but bi-allelic deletion of $5^{\prime}$ exons of ATM, has been observed in T-prolymphocytic leukaemia tumour DNA ${ }^{40}$ Possible explanations for non-detection of these three mutations include technical difficulties in FCCM, absent mRNA expression and other types of mutations, not detectable by RT-PCR analysis, eg gross deletions/insertions of the gene, RNA editing, position effect variegation, ${ }^{41}$ or gene modifiers altering expression or function of ATM ${ }^{42}$ The sensitivity of FCCM had previously been tested against a panel of eight known and seven 'blind' ATM mutations and all were detected (details not shown), making technical limitation of FCCM unlikely. Evidence for both mutant mRNA alleles being expressed was seen in all patients, except A-T 352, where no coding sequence variations were found. ATM has a relative paucity of coding sequence variants (5557G/A found in $0.82 / 0.18{ }^{43}$ is the most common), and therefore verifying that both mRNA alleles are expressed at adequate levels may prove impossible. $O$ ne of the undetected ATM mutations in A -T 352 may be a regulatory mutation in remote promoter elements, as reported for other genes, eg BRCA $1,{ }^{27}$ or may destabilise the mR NA so that only a single copy of the transcript is amplified. ${ }^{44}$

In summary, we have shown FCCM to be a fast, accurate and sensitive method for detecting mutations in ATM and have examined the resultant protein expression patterns in four A -T families. Three of the four novel mutations described are from Celtic/l rish families, which extends the known mutation repertoire in this population. The detection of both ATM mutations in three families, allows us to offer direct mutation-based prenatal tests for A - T in future pregnancies, which is preferable to and more accurate than the radiosensitive chromosomal breakage assay or linkage analysis. Finally, having confirmed the efficacy of FCCM, we can now use FCCM in further studies, testing the hypothesis that A - T heterozygotes may have increased susceptibility to breast cancer.

\section{Acknowledgements}

We thank Professor $Y$ Shiloh for ATM CDNA clones. We thank Jill Greenman, David Ellis, June Cameron, Chris $M$ athew and $M$ arketa Z velebil for their technical assistance and $M$ elissa B rown and $D$ avid $G$ rimwade for critical reading. Louise Izatt is funded by The Imperial Cancer Research Fund.

\section{References}

1 Swift M, Morrell D, Cromartie E, Chamberlin AR, Skolnick $\mathrm{MH}$, Bishop DT: The incidence and gene frequency of ataxia-telangiectasia in the $U$ nited States. A m J H um G enet 1986; 39: 573-583.

2 Woods CG, Bundey SE, Taylor A M : U nusual features in the inheritance of ataxia telangiectasia. H um G enet 1990; 84: 555-562.

3 Lavin MF, Shiloh Y: The genetic defect in ataxiatelangiectasia. A nnu Rev Immunol 1997; 15: 177-202.

4 Swift M, M orrell D, M assey R B, Chase CL: Incidence of cancer in 161 families affected by ataxia-telangiectasia. $\mathrm{N}$ Engl J Med 1991; 325: 1831-1836.

5 Bishop DT, Hopper J: AT-tributable risks? Nat Genet 1997; 15: 226

6 Gatti RA, Berkel I, Boder $E$ et al: Localization of an ataxia-telangiectasia gene to chromosome 11q22-23. Nature 1988; 336: 577-580.

7 Savitsky K, Bar-Shira A, G ilad S et al: A single ataxia telangiectasia gene with a product similar to $\mathrm{PI}-3$ kinase. Science 1995; 268: 1749-1753.

8 U ziel T, Savitsky K, Platzer M et al: G enomic organization of the ATM gene. Genomics 1996; 33: 317-320.

9 Platzer M, R otman G, B auer D et al: A taxia-telangiectasia locus: sequence analysis of $184 \mathrm{~kb}$ of human genomic D NA containing the entire ATM gene. Genome Res 1997; 7: $592-605$. 
10 Savitsky K, Sfez S, Tagle DA et al: The complete sequence of the coding region of the ATM gene reveals similarity to cell cycle regulators in different species. $\mathrm{H}$ um $\mathrm{M}$ ol $\mathrm{G}$ enet 1995; 4: 2025-2032.

11 Lakin ND, Weber P, Stankovic T, R ottinghaus ST, Taylor A M , Jackson SP: A nalysis of the A TM protein in wild-type and ataxia telangiectasia cells. Oncogene 1996; 13: 2707-2716.

12 Concannon P, Gatti RA: Diversity of ATM gene mutations detected in patients with ataxia-telangiectasia. $\mathrm{H} \mathrm{um}$ Mutat 1997; 10: 100-107.

13 Stankovic T, Kidd A M, Sutcliffe A et al: ATM mutations and phenotypes in ataxia-telangiectasia families in the British Isles: expression of mutant ATM and the risk of leukemia, lymphoma, and breast cancer. A m J H um G enet 1998; 62: 334-345.

14 Gilad S, B ar-Shira A, H arnik R et al: A taxia-telangiectasia: founder effect among north A frican Jews. $\mathrm{H}$ um $\mathrm{M} \mathrm{ol}$ G enet 1996; 5: 2033-2037.

15 Telatar M, Wang Z, U dar N et al: A taxia-telangiectasia: mutations in ATM CDNA detected by protein-truncation screening. A m J H um G enet 1996; 59: 40-44.

16 W right J, Teraoka S, O nengut S et al: A high frequency of distinct ATM gene mutations in ataxia-telangiectasia. A m J $\mathrm{H}$ um G enet 1996; 59: 839-846.

17 Toyoshima M, Hara T, Zhang $\mathrm{H}$ et al: A taxia-telangiectasia without immunodeficiency: novel point mutations within and adjacent to the phosphatidylinositol 3-kinaselike domain. A m J M ed G enet 1998; 75: 141-144.

18 G ilad S, K hosravi R, H arnik R et al: I dentification of A T M mutations using extended RT-PCR and restriction endonuclease fingerprinting, and elucidation of the repertoire of A -T mutations in I srael. H um M utat 1998; 11: 69-75.

19 van Belzen $M J, H$ iel JA, Weemaes $C M$ et al: $A$ double missense mutation in the ATM gene of a Dutch family with ataxia telangiectasia. $\mathrm{H}$ um Genet 1998; 102: 187-191.

20 Rowley G, Saad S, G iannelli F, G reen PM : U Itrarapid mutation detection by multiplex, solid-phase chemical cleavage. G enomics 1995; 30: 574-582.

21 G reenman J, M ohammed S, E llis D et al: I dentification of missense and truncating mutations in the BR CA 1 gene in sporadic and familial breast and ovarian cancer. Genes Chromosomes Cancer 1998; 21: 244-249.

22 Taylor A M , Flude E, L aher B et al: Variant forms of ataxia telangiectasia. J M ed G enet 1987; 24: 669-677.

23 M iller SA, Dykes DD, Polesky HF: A simple salting out procedure for extracting DNA from human nucleated cells. Nucleic A cids Res 1988; 16: 1215.

24 Chomczynski P, Sacchi N: Single-step method of RNA isolation by acid guanidinium thiocyanate-phenol-chloroform extraction. A nal Biochem 1987; 162: 156-159.

25 Whittock NV, Roberts RG, Mathew CG, A bbs SG: Dystrophin point mutation screening using a multiplexed protein truncation test. G enetic Testing 1997; 1: 115-123.

26 D on RH, Cox PT, Wainwright BJ, Baker K, Mattick J S: 'Touchdown' PCR to circumvent spurious priming during gene amplification. N ucleic A cids Res 1991; 19: 4008.

$27 \mathrm{Xu} \mathrm{CF}$, Chambers JA, Nicolai $\mathrm{H}$ et al: Mutations and alternative splicing of the BRCA 1 gene in UK breast/ ovarian cancer families. Genes Chromosomes Cancer 1997; 18: 102-110.
28 Gallagher S, Winston SE, Fuller SA, Hurrell JGR: Immunoblotting and immunodetection. In: A usubel FM $B R$, K ingston RE, Moore DD, Seidman JG, Smith JA, Struhl K (eds). Current Protocols in Molecular Biology. John Wiley: N ew York, 1997, 10.8, pp 1-21.

29 McConville CM, Stankovic T, Byrd PJ et al: Mutations associated with variant phenotypes in ataxia-telangiectasia. A m J H um G enet 1996; 59: 320-330.

30 Pecker I, A vraham K B, G ilbert DJ et al: I dentification and chromosomal localization of $A \mathrm{tm}$, the mouse homolog of the ataxia-telangiectasia gene. G enomics 1996; 35: 39-45.

31 G ilad S, Chessa L, K hosravi R et al: G enotype-phenotype relationships in ataxia-telangiectasia and variants. A $\mathrm{m} J$ H um G enet 1998; 62: 551-561.

32 Verpy $E, B$ iasotto $M$, M eo T, Tosi M : E fficient detection of point mutations on color-coded strands of target DNA. Proc Natl A cad Sci USA 1994; 91: 1873-1877.

33 ATM D atabase: http://www.vmmc.org/vmrc/atm.htm

34 Krawczak $M$, Reiss J, Cooper DN: The mutational spectrum of single base-pair substitutions in mR NA splice junctions of human genes: causes and consequences. $\mathrm{H}$ um G enet 1992; 90: 41-54.

35 J pred: http://barton.ebi.ac.uk

36 Pakula A A, Sauer RT: G enetic analysis of protein stability and function. A nnu Rev G enet 1989; 23: 289-310.

37 Hecht M H, Nelson HC, Sauer RT: Mutations in lambda repressor's amino-terminal domain: implications for protein stability and DNA binding. Proc Natl A cad Sci USA 1983; 80: 2676-2680.

38 Byrd PJ, McConville CM, Cooper P et al: Mutations revealed by sequencing the $5^{\prime}$ half of the gene for ataxia telangiectasia. H um M ol G enet 1996; 5: 145-149.

39 Byrd PJ, Cooper PR, Stankovic T et al: A gene transcribed from the bidirectional ATM promoter coding for a serine rich protein: amino acid sequence, structure and expression studies. H um M ol G enet 1996; 5: 1785-1791.

40 Stilgenbauer S, Schaffner C, Litterst A et al: Biallelic mutations in the ATM gene in T-prolymphocytic leukemia. Nat M ed 1997; 3: 1155-1159.

41 Bedell MA, Jenkins NA, Copeland NG: Good genes in bad neighbourhoods. Nat G enet 1996; 12: 229-232.

42 Brown M A : Tumor suppressor genes and human cancer. A dv G enet 1997; 36: 45-135.

43 Vorechovsky I, Luo L, Lindblom A et al: ATM mutations in cancer families. Cancer Res 1996; 56: 4130-4133.

44 R oy N, Laflamme G, Raymond V: 5' untranslated sequences modulate rapid $\mathrm{mRNA}$ degradation mediated by $3^{\prime} \mathrm{AU}$-rich element in $\mathrm{V}$-/c-fos recombinants. Nucleic A cids Res 1992; 20: 5753-5762.

45 Taylor AMR, Hernandez D, McConville CM et al: $M$ alignant disease and variations in radiosensitivity in ataxia telangiectasia patients. In: E eles R A, Ponder BA J, Easton DF, Horwich D (eds). G enetic Predisposition to Cancer. Chapman and H all: L ondon, 1996, pp 138-151.

46 Bundey S: Clinical and genetic features of ataxia-telangiectasia. Int J Radiat Biol 1994; 66: S23-29.

47 G enome D atabase: http://www.gdb.org

48 A ntonarakis SE : R ecommendations for a nomenclature system for human gene mutations. N omenclature Working G roup. Hum Mutat 1998; 11: 1-3. 